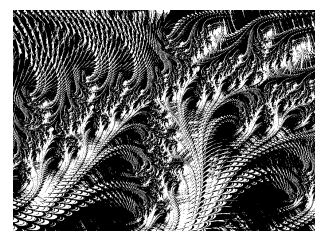

https://doi.org/10.5559/di.30.3.01

\title{
SELF-REGULATION, NORMATIVE BELIEFS, ALCOHOL USE AND CONSEQUENCES AMONG UNIVERSITY STUDENTS FROM EASTERN EUROPE
}

Ondrej KALINA, Olga OROSOVA

Faculty of Arts, Pavol Jozef Safarik University in Kosice, Kosice, Slovakia

Vilma KRIAUCIONIENE

Faculty of Public Health, Lithuanian University of Health Sciences, Kaunas, Lithuania

Andrea LUKÁCS

Faculty of Health Care, University of Miskolc, Miskolc, Hungary

Michal MIOVSKY

1st Medical Faculty, Charles University, Prague, Czech Republic

UDK: 159.947-057.875:178.1(4-11)

Original scientific paper

Received: September 10, 2019

This work was supported by the Slovak Research and Development Agency under Contract No. APVV-15-0662 and the Slovak Academy of Sciences under Contract No.

VEGA $1 / 0523 / 20$.
This study aims to explore the associations between descriptive normative beliefs (DNB), alcohol use and negative consequences and test whether self-regulation (SR) moderates this relationship. The data was collected online from 1621 first-year university students in the Czech Republic, Hungary, Lithuania and Slovakia. The AUDIT, self-regulation questionnaire and questions regarding DNB were used. DNB were found to be positively associated with drinking across all the samples. The associations between DNB and alcohol use as well as between alcohol use and negative consequences were stronger among students with lower SR. The protective effect of SR on alcohol use and consequences combined with the theory of social influence may improve intervention accuracy and make it a promising target for intervention among young adults.

Keywords: self-regulation, descriptive normative beliefs, alcohol use consequences, first-year university students

Ondrej Kalina, Department of Educational Psychology and Health Psychology, Faculty of Arts, Pavol Jozef Safarik University in Kosice, Moyzesova 9, Kosice 041 80, Slovakia. 
High levels of alcohol consumption are undoubtedly one of the most serious health and public issues across Europe. In addition to other licit and illicit drugs, alcohol causes more than $4 \%$ of all deaths in the EU for those aged between 25 and 39 (European Monitoring Centre for Drugs and Drug Addiction, 2019). The pattern of alcohol consumption among students during the first year at university is typically characterised by heavy episodic consumption (four/five drinks per occasion for male/female). This pattern of drinking can also be described as binge drinking (Baer et al., 1995; Lorant \& Nicaise, 2015). This binge drinking style may lead to a range of negative consequences such as cognitive and neurological impairments, alcohol dependence, blackouts, personal injuries or death, academic failure and skipping classes as well as psychological problems (Boot et al., 2012; Corbin et al., 2011). There are two main factors which are partially responsible for this high consumption of alcohol. Firstly, going to university is often the first long-term experience for young people without direct parental supervision. Therefore, students at this stage pursue novel, intense and often risky experiences with greater freedom and lack of supervision than in any other developmental period (Meisel \& Barnett, 2017). Secondly, university life brings new challenges for students as they need to adapt to a new environment, peers and relationships. Although this process is highly individual, students often follow informal community rules to facilitate this adaptation process. Some of them consume alcohol in peer group gatherings supporting their perception of being socially accepted by receiving positive feedback. However, at the same time they are exposed to social influences which may strongly modify their perception of some behaviours and social norms. It has been documented that university students often overestimate the amount and frequency of their peers' alcohol consumption (Brutovská et al., 2015; Vallentin-Holbech et al., 2017; Dempsey et al., 2018). Such misperceptions of descriptive norms may increase an individual's alcohol consumption in an attempt to match their own perception of descriptive normative beliefs (DNB) (Borsari \& Carey, 2003; Brutovská et al., 2015). In potentially novel, uncertain or threatening situations, descriptive social information works as a decision-making heuristic. While it saves time and effort in searching for useful and accurate behaviours, it may navigate an individual's behaviour towards negative outcomes such as heavy episodic drinking (Griskevicius et al., 2006; Cialdini, 2009). Thus, new students in particular may often face situations of short-term immediate rewards such as social acceptance by using alcohol. This may conflict 
DRUŠ. ISTRAŽ. ZAGREB GOD. 30 (2021), BR. 3, STR. 467-485

KALINA, O. ET AL.: SELF-REGULATION.. with their long-term aims of being healthy and making progress in their studies (Jacobson et al., 2011). The fundamental function of self-regulation is to determine whether and to what extent the long-term goal will be maintained (Baumeister \& Vohs, 2007).

Self-regulation (SR) is defined as the capacity to alter or override dominant response tendencies and to regulate emotions, thoughts, attention and behaviour to reach an aim as it enables one to plan things and delay gratification (Hofmann et al., 2009; Reynolds et al., 2008). Higher levels of SR protect late adolescents and young adults from drinking and indulging in other risk behaviours (Vohs \& Baumeister, 2011). There is also strong evidence that higher SR may operate with an overall effect and also with a buffering effect towards different types of health risk behaviours (Lindgren et al., 2014; Hustad et al., 2009; Quinn \& Fromme, 2010). Some studies have described the different effects of SR, and Hall (2013) found that SR was significantly associated with the frequency and amount of alcohol use. In other cases, it has been associated with only the consequences of alcohol (Carey et al., 2004). Thus, it is not clear whether the primary function of SR is to decrease the frequency and amount of alcohol use or whether it plays a more crucial role in acting against negative alcohol consequences.

\section{OBJECTIVE OF THE STUDY}

This cross-sectional study investigates whether self-regulation moderates the association between descriptive normative beliefs, alcohol use, dependence symptoms and harmful alcohol use among first year university students from four Eastern European countries. Therefore, the study will examine: (1) whether the positive associations between DNB and alcohol use are moderated by SR; (2) whether the positive associations between alcohol use and dependence symptoms are moderated by SR; (3) whether the positive associations between alcohol use and harmful alcohol use are moderated by SR. It is also expected that the associations between SR, DNB, alcohol use and negative consequences will differ according to country.

\section{METHODS}

\section{Study sample and procedure}

The participants were recruited from the Student Life Cohort in Europe (SLiCE) which is a European study carried out among first-year university students. This analysis is based on data from students in the Czech Republic, Hungary, Lithuania and Slo- 
DRUŠ. ISTRAŽ. ZAGREB GOD. 30 (2021), BR. 3, STR. $467-485$

KALINA, O. ET AL.: SELF-REGULATION..

(1) TABLE 1

Attrition analysis by age, sex, parental education and monthly income vakia collected during the winter term of 2016. Students were asked to complete self-administered online questionnaires. The universities in the Czech Republic (Brno University of Technology, Charles University in Prague), Lithuania (Vytautas Magnus University; Lithuanian University of Health Sciences; Kaunas University of Technology; Aleksandras Stulginskis University) and Slovakia (P. J. Safarik University; University of Presov) provided the research team with the email addresses of all enrolled students in their first year. These students were directly invited to participate in the survey by email while the Hungarian students (University of Miskolc; Eötvös Loránd University in Budapest) were reached through university newsletters and the student educational administration system. Student participation in all countries was voluntary and anonymous. Students were told that by completing the questionnaire they would be providing informed consent and were also notified that they could withdraw at any point while filling in the questionnaire. No incentives were provided. Permission to conduct the study was granted by the Ethics Committees of the participating institutions. The initial total sample included 2671 students. Only the students who had completely filled in the questionnaires concerning self-regulation, alcohol use and normative beliefs were included. Due to this selection, an attrition analysis was carried out (Table 1) and the sex, age, parental education and income was compared between those who were included and not included in the study.

\begin{tabular}{|c|c|c|c|c|c|c|}
\hline & & \multicolumn{2}{|c|}{$\begin{array}{r}\text { Study sample } \\
n=1621\end{array}$} & \multicolumn{2}{|c|}{$\begin{array}{r}\text { Attrition cases } \\
n=1050 \\
\end{array}$} & \multirow[b]{2}{*}{$P$-value } \\
\hline & & Mean & $S D$ & Mean & $S D$ & \\
\hline \multirow{3}{*}{\multicolumn{2}{|c|}{$\begin{array}{l}\text { Age } \\
\text { Average monthly income (euro) }\end{array}$}} & 20.62 & 2.83 & 20.62 & 3.49 & $0.963^{\mathrm{a}}$ \\
\hline & & 422.82 & 700.68 & 408.60 & 640.08 & $0.340^{\mathrm{a}}$ \\
\hline & & $n$ & $\%$ & $n$ & $\%$ & \\
\hline \multirow[t]{2}{*}{ Sex } & Males & 438 & 27.02 & 298 & 28.40 & $0.066^{\mathrm{b}}$ \\
\hline & Females & 1183 & 72.98 & 752 & 71.60 & \\
\hline \multirow[t]{3}{*}{ Mother education } & Elementary & 123 & 7.60 & 135 & 12.80 & \\
\hline & Higher education & 1198 & 73.90 & 647 & 61.60 & $0.002^{\mathrm{b}}$ \\
\hline & University & 300 & 18.50 & 268 & 25.60 & \\
\hline \multirow[t]{3}{*}{ Father education } & Elementary & 237 & 14.60 & 254 & 24.20 & \\
\hline & Higher education & 1143 & 70.50 & 632 & 60.20 & $0.003^{\mathrm{b}}$ \\
\hline & University & 241 & 14.90 & 164 & 15.60 & \\
\hline
\end{tabular}

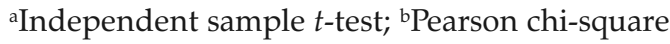


DRUŠ. ISTRAŽ. ZAGREB GOD. 30 (2021), BR. 3, STR. 467-485

KALINA, O. ET AL.: SELF-REGULATION..

\section{Measures}

The results showed that the students only differed in the educational levels of their parents. Therefore, the study sample can be considered unbiased regarding sex, age and parental income. The final research sample consisted of 1621 students: 317 from the Czech Republic (mean age 20.5; $S D=5.8 ; 66.6 \%$ females); 426 from Hungary (mean age 21.8; $S D=4.7 ; 75.3 \%$ females), 373 from Lithuania (mean age 20.5; $S D=3.2 ; 76.0 \%$ females), and 505 from Slovakia (mean age 20.0; $S D=1.5$; $74.1 \%$ females). The sample was ethnically homogeneous as more than $94 \%$ of respondents from each country claimed that particular ethnicity. The legal age for alcohol consumption across countries was 18 .

Self-regulation was measured by the Short Self-Regulation Questionnaire (SSRQ) (Carey et al., 2004) which contains 31 items. The items are scored on a 1-5 scale (strongly disagree-strongly agree) with a higher score indicating higher self-regulation.

Cronbach's alpha in the study ranged from 0.88 to 0.97 .

Previous research looking at young American university students has indicated that the SSRQ has a single factor that represents overall self-regulation capacity as well as revealing the possibility of two distinct factors (i.e. impulse control and goal setting) with acceptable reliability and validity (Neal \& Carey, 2005).

Alcohol consumption and alcohol consequences among university students were assessed by AUDIT (Babor et al., 2001). This is a 10-item alcohol screening test which detects risky drinking. Three types of outcome measures were used as proposed in AUDIT: (1) hazardous alcohol use (conceptualised in the current study as alcohol consumption); (2) dependence symptoms and (3) harmful alcohol use. Hazardous alcohol use -3 items (frequency of drinking, typical quantity, frequency of heavy drinking) was evaluated on a 5-point scale from 0 to 4; Dependence symptoms - 3 items (impaired control over drinking, increased salience of drinking, morning drinking) evaluated on a 5-point scale from 0 to 4; Harmful alcohol use -4 items (guilt after drinking, blackouts, alcohol-related injuries, others concerned about drinking). The first 8 items were scored on a 5-point scale from 0 to 4 (0-never, 1-less than monthly, 2-monthly, 3-weekly, 4-daily or almost daily) while the last two items were scored on a 3-point scale from 0 to 4 (0-no, 2-yes but not in the last year, 4-yes, during the last year). The sum score ranges from 0-12 for hazardous alcohol use and for dependency symptoms and from 0-16 for harmful alcohol use. A higher value in each domain represents a higher level of use or symptoms. Cronbach's alphas ranged from 0.67 to 0.72 . 
DRUŠ. ISTRAŽ. ZAGREB

GOD. 30 (2021), BR. 3, STR. 467-485

KALINA, O. ET AL.: SELF-REGULATION..
Descriptive normative beliefs were assessed by a set of three questions about the individual perception of a typical student's alcohol use. The items were consistently formulated with items from the alcohol use domain. The items related to the behaviour of a typical student, e.g. "How often do you think a typical student at ...[university]... has a drink containing alcohol?" The same 5-point scale was used as that in the AUDIT test. The sum of the items ranges from 0 to 12 where a higher score represents descriptive normative beliefs of higher alcohol use by a typical student. Cronbach's alpha varies across the countries from 0.63 to 0.71 .

\section{Procedures and statistical analysis}

Firstly, a correlation and means comparison of the output and independent variables by country using a one-way ANOVA was carried out. The effect size was calculated using partial Eta-squared estimating of effect size (Partial $\eta^{2}$ ). Following this, the study looked at whether SR moderates the relationship between normative beliefs and alcohol consumption as well as if SR moderates the impact of alcohol consumption on dependence symptoms and harmful alcohol use. In order to do this, hierarchical regressions (IBM SPSS 21.0) were performed and three models were tested to predict the outcome variables: (1) alcohol consumption; (2) dependence symptoms and (3) harmful alcohol use. In each model, the independent variables were firstly entered into the analyses and secondly the interaction term was added. In the models predicting dependence symptoms and harmful alcohol use, alcohol consumption was used as the independent variable. All models were run separately for each country and were controlled for gender.

In order to determine if the interaction followed the expected pattern, a simple slope test was performed considering one standard deviation high and low values from the mean values of self-regulation. A simple slope test is useful to determine the specific effect of a predictor on an outcome variable at different values of a moderator.

\section{RESULTS}

\section{Descriptive statistics}

As shown in Table 2, the average values of the explored variables differ according to country. The averages of SR differ between the groups $[F(3)=31.11, p<0.001)]$. The highest average scores were observed among the Hungarian students $(M=115.76)$ while the lowest average scores were observed in the Slovak sample $(M=106.50)$. The average scores of alco- 
DRUŠ. ISTRAŽ. ZAGREB GOD. 30 (2021), BR. 3, STR. 467-485

KALINA, O. ET AL.: SELF-REGULATION..

(1) TABLE 2

Differences in self-regulation, alcohol use, normative beliefs and consequences by country hol consumption were the highest among the students from the Czech Republic $(M=3.73)$, who also reported the highest average rates of normative beliefs $(M=6.97)$. The same pattern was reported among students from Lithuania, as they scored the lowest in alcohol consumption $(M=3.22)$ and also had the lowest scores in normative beliefs $(M=5.87)$. The highest average scores of dependence symptoms were reported by the Czech students $(M=0.76)$, while the Hungarian students had the lowest score $(M=0.33)$. Similarly, the highest and lowest average scores of negative alcohol consequences were reported by the Czech students $(M=1.72)$ and Hungarian students $(M=1.11)$ respectively. However, all significant differences were very low in effect size.

\begin{tabular}{llrrrrr}
\hline & & \multicolumn{3}{c}{} & \multicolumn{2}{c}{ Variables (range) } \\
\cline { 2 - 7 } & & $\begin{array}{r}\text { Self- } \\
\text {-regulation } \\
(31-155)\end{array}$ & $\begin{array}{r}\text { Alcohol } \\
\text { consumption } \\
(0-12)\end{array}$ & $\begin{array}{r}\text { Normative } \\
\text { beliefs } \\
(0-12)\end{array}$ & $\begin{array}{r}\text { Dependence } \\
\text { symptoms } \\
(0-12)\end{array}$ & $\begin{array}{r}\text { Harmful } \\
\text { alcohol use } \\
(0-16)\end{array}$ \\
\hline Czech Republic & $M$ & 108.13 & 3.73 & 6.97 & 0.76 & 1.72 \\
$(n=317)$ & $S D$ & 16.65 & 2.09 & 1.74 & 1.34 & 2.22 \\
Hungary & $M$ & 115.76 & 3.30 & 6.18 & 0.34 & 1.12 \\
$(n=426)$ & $S D$ & 17.48 & 2.02 & 1.82 & 0.93 & 1.84 \\
Lithuania & $M$ & 109.10 & 3.22 & 5.87 & 0.48 & 1.21 \\
$(n=373)$ & $S D$ & 13.70 & 2.07 & 1.74 & 0.99 & 1.90 \\
Slovak Republic & $M$ & 106.50 & 3.68 & 6.55 & 0.63 & 1.71 \\
$(n=505)$ & $S D$ & 13.27 & 2.23 & 1.83 & 1.27 & 2.53 \\
One-way Anova & $p$ & 0.000 & 0.001 & 0.000 & 0.000 & 0.000 \\
& Partial $\eta^{2}$ & 0.055 & 0.011 & 0.044 & 0.018 & 0.017 \\
\hline
\end{tabular}

Table 3 presents the correlations for the study variables. As expected, descriptive normative beliefs were positively correlated with alcohol consumption in all the samples except in the Czech Republic. The proposed moderator in the current study negatively correlated with most of the alcohol-related variables in all the study samples except in Slovakia. Alcohol consumption, alcohol dependence symptoms and alcohol harmful consequences scores were moderately and positively correlated with one another. These correlations provide initial support for a positive relationship between DNB and alcohol consumption and between alcohol consumption and dependence symptoms and harmful alcohol use. Given that correlations are only one-to-one linkages between variables, hierarchical regression was carried out. This enables incremental changes to be detected in the amount of explained variance of dependent variable before and after adding a set of independent and control variables (Cohen \& Cohen, 1983). 


\begin{tabular}{|c|c|c|c|c|c|}
\hline & & Audit C & Audit D & Audit $\mathrm{H}$ & DNB \\
\hline \multirow[t]{5}{*}{ Czech Republic } & Audit C & 1 & & & \\
\hline & Audit D & $0.565^{* *}$ & 1 & & \\
\hline & Audit H & $0.591^{* *}$ & $0.565^{* *}$ & 1 & \\
\hline & DNB & 0.050 & -0.014 & 0.035 & 1 \\
\hline & SR & $-0.161^{* *}$ & $-0.188^{* *}$ & $-0.121^{*}$ & 0.014 \\
\hline \multirow[t]{5}{*}{ Hungary } & Audit C & 1 & & & \\
\hline & Audit D & $0.378^{* *}$ & 1 & & \\
\hline & Audit $\mathrm{H}$ & $0.369^{* *}$ & $0.597^{* *}$ & 1 & \\
\hline & DNB & $0.326^{* *}$ & $0.094^{*}$ & 0.086 & 1 \\
\hline & SR & $-0.212^{* *}$ & $-0.232^{* *}$ & $-0.236^{* *}$ & -0.006 \\
\hline \multirow[t]{5}{*}{ Lithuania } & Audit C & 1 & & & \\
\hline & Audit D & $0.404^{* *}$ & 1 & & \\
\hline & Audit H & $0.416^{* *}$ & $0.529 * *$ & 1 & \\
\hline & DNB & $0.344^{* *}$ & $0.110^{* *}$ & $0.176^{* *}$ & 1 \\
\hline & SR & -0.097 & $-0.193^{* *}$ & $-0.173^{* *}$ & -0.060 \\
\hline \multirow[t]{5}{*}{ Slovak Republic } & Audit C & 1 & & & \\
\hline & Audit D & $0.442^{* *}$ & 1 & & \\
\hline & Audit $\mathrm{H}$ & $0.499^{* *}$ & $0.616^{* *}$ & 1 & \\
\hline & DNB & $0.360^{* *}$ & $0.192^{* *}$ & $0.177^{* *}$ & 1 \\
\hline & SR & 0.080 & -0.054 & -0.057 & -0.014 \\
\hline
\end{tabular}

D TABLE 3

Pearson correlations among explored variables
$\mathrm{DNB}=$ normative beliefs; $\mathrm{SR}=$ self-regulation; Audit $\mathrm{C}=$ alcohol consumption; Audit $\mathrm{D}=$ alcohol dependence symptoms; Audit $\mathrm{H}=$ harmful alcohol use

\section{Self-regulation as a protective factor against alcohol consumption - moderation analysis}

In Table 4, the regression coefficients for the Hungarian, Lithuanian and Slovak students in Model 1a show that higher rates of DNB predicted higher consumption of alcohol (HU: $\beta=$ $0.134, p<0.001$; LI: $\beta=0.123, p<0.001$; SK: $\beta=0.102, p<0.001$ ). The interaction term of DNB and SR in Model 2a had significant impact on alcohol consumption among Czech and Slovak students (CZ: $\beta=-0.126^{*}, p<0.05$; SK: $\beta=-0.297^{*}, p<0.01$ ) with significant values of $\Delta R^{2}$. Table 7 presents the condition effect of $\pm 1 S D$ moderator (SR) on the relationship between normative beliefs and alcohol consumption. With low levels of SR (-1 SD) the explored relationship was significant among Czech and Slovak students (CZ: $\mathrm{b}=0.191, p<0.05$; SK: $\mathrm{b}=$ $0.545, p<0.001)$. With high levels of SR $(+1 S D)$, the explored relationship was only significant in the Slovak sample (SK: $\mathrm{b}=$ $0.329, p<0.001)$. Among Slovak students, the effect of normative beliefs on alcohol consumption in the condition of high SR (+1 SD) remains positive, but the levels of b-estimates dropped compared to the low SR (-1 SD) condition. Therefore, it can be concluded that high levels of SR buffer the detrimental effect of normative beliefs on alcohol consump- 
tion among students from the Czech Republic and Slovakia. A graphical representation of this pattern is presented in Figure 1.

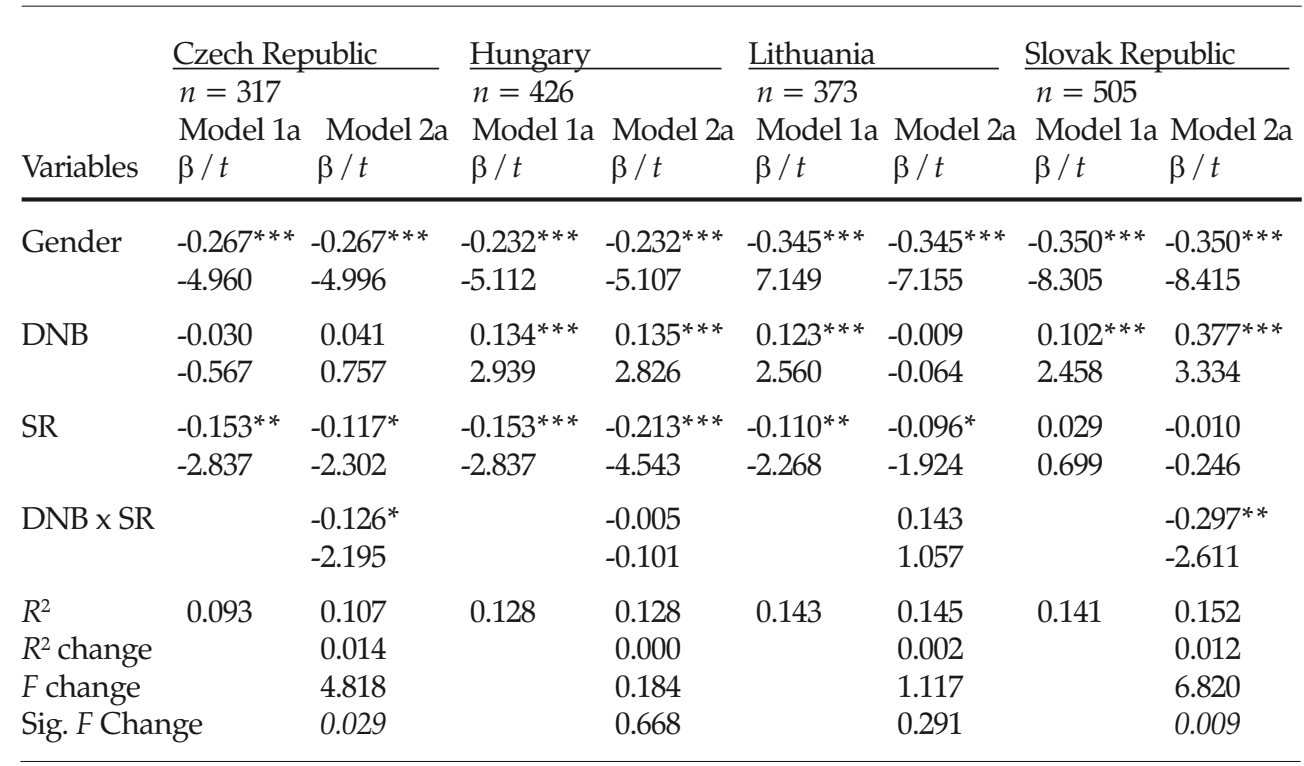

(1) TABLE 4

Regression models predicting alcohol consumption

๑ FIGURE 1

Moderation effect of self-regulation on relationship between descriptive normative beliefs and alcohol consumption by country
$\mathrm{DNB}=$ Descriptive normative beliefs; $\mathrm{SR}=$ Self-regulation ${ }^{*} p<0.05,{ }^{* *} p<0.01,{ }^{* *} p<0.001$

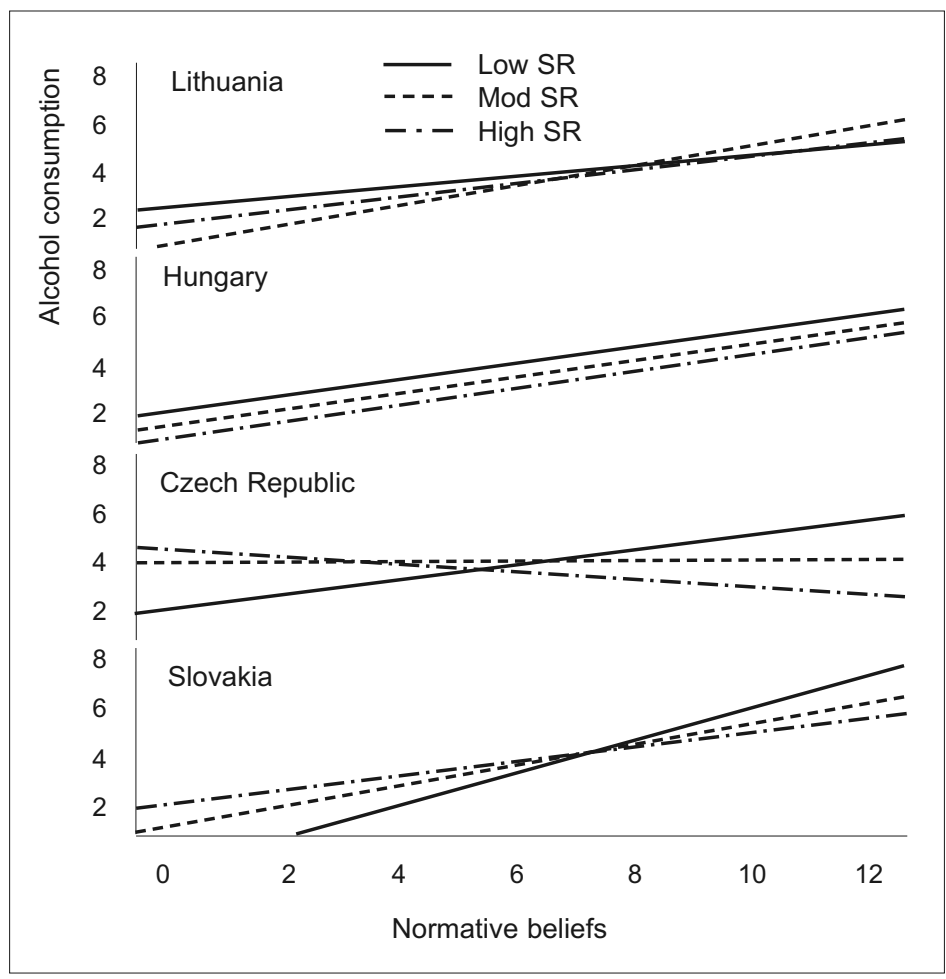




\section{Self-regulation as a protective factor against dependence symptoms}

(1) TABLE 5

Regression models predicting dependence symptoms
In Table 5, the regression coefficients in Model $1 \mathrm{~b}$ show that the rates of alcohol consumption significantly predicted higher rates of dependence symptoms in all the countries (CZ: $\beta=$ $0.547, p<0.001$, HU: $\beta=0.318, p<0.001$; LI: $\beta=0.414, p<0.001$; SK: $\beta=0.419, p<0.001)$. The interaction term of AU and SR in Model $2 \mathrm{~b}$ had a significant impact on the dependence symptoms among the Czech, Hungarian and Lithuanian students (CZ: $\beta=-0.19^{*}, p<0.001$; SK: $\beta=-0.148^{*}, p<0.01$, LI: $\beta=-0.094, p<0.05)$ with significant values of $\Delta R^{2}$.

Table 8 presents the condition effect of $\pm 1 S D$ moderator (SR) on the relationship between alcohol consumption and dependence symptoms. With a low level of alcohol consumption $(-1 S D)$, the explored relationship was significant among the Czech, Hungarian and Lithuanian students (CZ: b $=0.446$, $p<0.001$; HU: $\mathrm{b}=0.245, p<0.001$; LI: $\mathrm{b}=0.262, p<0.001)$. With a high level of SR $(+1 S D)$, the explored relationship remained positively significant in the Czech Republic, Hungary and Lithuania (CZ: $\mathrm{b}=0.211, p<0.001 ; \mathrm{HU}: \mathrm{b}=0.075$, $p<0.05$; LI: $\mathrm{b}=0.121, p<0.001$ ), although the levels of b-estimates dropped compared to the low SR (-1 SD) condition. Therefore, it can be concluded that high levels of SR buffer the detrimental effect of alcohol consumption on dependence symptoms among students from the Czech Republic, Hungary and Lithuania. A graphical representation of this pattern is presented in Figure 2.

\begin{tabular}{|c|c|c|c|c|c|c|c|c|}
\hline & Czech Rep & public & Hungary & & Lithuania & & Slovak Re & public \\
\hline & $n=317$ & & $n=426$ & & $n=373$ & & $n=505$ & \\
\hline & Model 1b & Model 2b & Model 1b & Model 2b & Model 1b & Model 2b & Model 1b & Model 2b \\
\hline Variables & $\beta / t$ & $\beta / t$ & $\beta / t$ & $\beta / t$ & $\beta / t$ & $\beta / t$ & $\beta / t$ & $\beta / t$ \\
\hline Gender & 0.036 & 0.039 & 0.053 & -0.050 & -0.045 & -0.047 & -0.067 & -0.187 \\
\hline & 0.762 & 0.836 & 1.174 & -1.152 & -0.912 & -0.870 & -1.573 & -1.504 \\
\hline $\mathrm{AC}$ & $0.547^{* * *}$ & $0.515^{* * *}$ & $0.318^{* * *}$ & $0.360^{* * *}$ & $0.413^{* * *}$ & $0.407^{* * *}$ & $0.419 * * *$ & $0.285^{* * *}$ \\
\hline & 11.197 & 10.273 & 6.774 & 7.421 & 8.337 & 8.216 & 9.81 & 4.789 \\
\hline SR & $-0.105^{*}$ & $-0.092^{*}$ & $-0.164^{* * *}$ & $-0.162^{* * *}$ & $-0.108^{*}$ & $-0.118^{*}$ & $0.108^{* *}$ & -0.127 \\
\hline & -2.227 & -1.994 & -3.621 & -3.597 & -2.309 & -2.506 & 2.703 & -1.827 \\
\hline$A C \times S R$ & & $-0.19^{* * *}$ & & $-0.148^{* *}$ & & $-0.094^{*}$ & & -0.021 \\
\hline & & -4.093 & & -3.249 & & -2.031 & & -0.514 \\
\hline$R^{2}$ & 0.318 & 0.353 & 0.165 & 0.185 & 0.204 & 0.222 & 0.205 & 0.205 \\
\hline$R^{2}$ change & & 0.035 & & 0.020 & & 0.018 & & 0.001 \\
\hline$F$ change & & 16.751 & & 10.558 & & 4.124 & & 0.263 \\
\hline Sig. F Char & nge & 0.000 & & 0.001 & & 0.003 & & ns. \\
\hline
\end{tabular}

$\mathrm{AC}=$ Alcohol consumption; SR $=$ Self-regulation; ${ }^{*} p<0.05,{ }^{* *} p<0.01,{ }^{* *} p<0.001$ 
DRUŠ. ISTRAŽ. ZAGREB GOD. 30 (2021), BR. 3, STR. 467-485

KALINA, O. ET AL.: SELF-REGULATION..

$\rightarrow$ FIGURE 2

Moderation effect of self-regulation on relationship between alcohol consumption and dependence symptoms by country

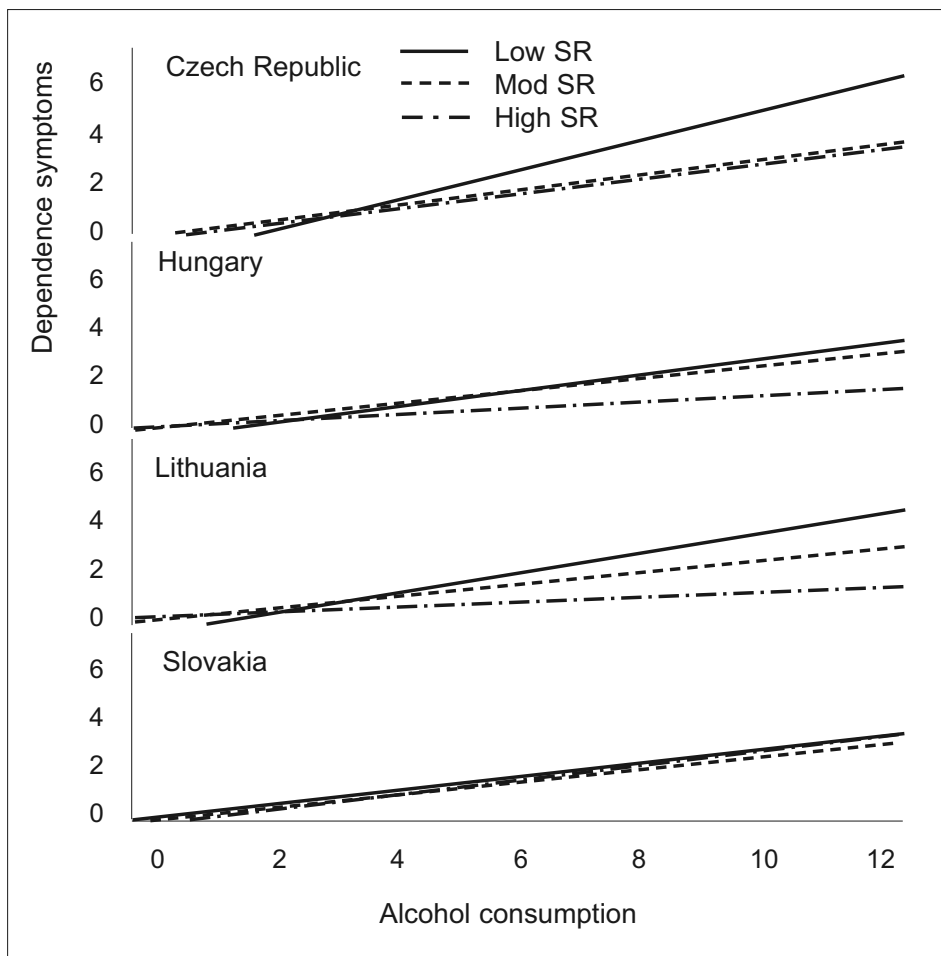

\section{Self-regulation as a protective factor against} harmful alcohol consequences - moderation analysis

In Table 6, the regression coefficients in Model 1c show that higher rates of alcohol use significantly predicted higher rates of harmful alcohol consequences in all the countries (CZ: $\beta=$ $0.507, p<0.001$, HU: $\beta=0.305, p<0.001$; LI: $\beta=0.361, p<0.001$; SK: $\beta=0.479, p<0.001)$. The interaction term of alcohol consumption and SR in Model 2c had a significant impact on harmful alcohol use among the Hungarian, Lithuanian and Slovak students (HU: $\beta=-0.156, p<0.001$; LI: $\beta=-0.087, p<0.05$, SK: $\beta=-0.106, p<0.05)$ with significant values of $\Delta R^{2}$.

Table 8 presents the condition effect of $\pm 1 S D$ moderator (SR) on the relationship between alcohol consumption and harmful alcohol use. With a low level of AU (-1 SD) the explored relationship was significant among the Hungarian, Lithuanian and Slovak students (HU: $\mathrm{b}=0.456, p<0.001 ; \mathrm{LI}: \mathrm{b}=$ $0.486, p<0.001, \mathrm{SK}: \mathrm{b}=0.718, p<0.001)$. With a high level of SR (+1 SD), the explored relationship in Lithuania, Hungary and Slovakia remains positively significant (LI: $b=0.149, p<$ 0.01 ; HU: $b=0.29, p<0.05$; SK: $b=0.458, p<0.001)$, although the levels of b-estimates dropped compared to the low SR (-1 SD) condition. Therefore, it can be concluded that high levels of SR buffer the detrimental effect of alcohol con- 
(1) TABLE 6

Regression models predicting harmful alcohol consumption sumption on harmful alcohol use among students from Hungary, Lithuania and Slovakia. A graphical representation of this is presented in Figure 3.

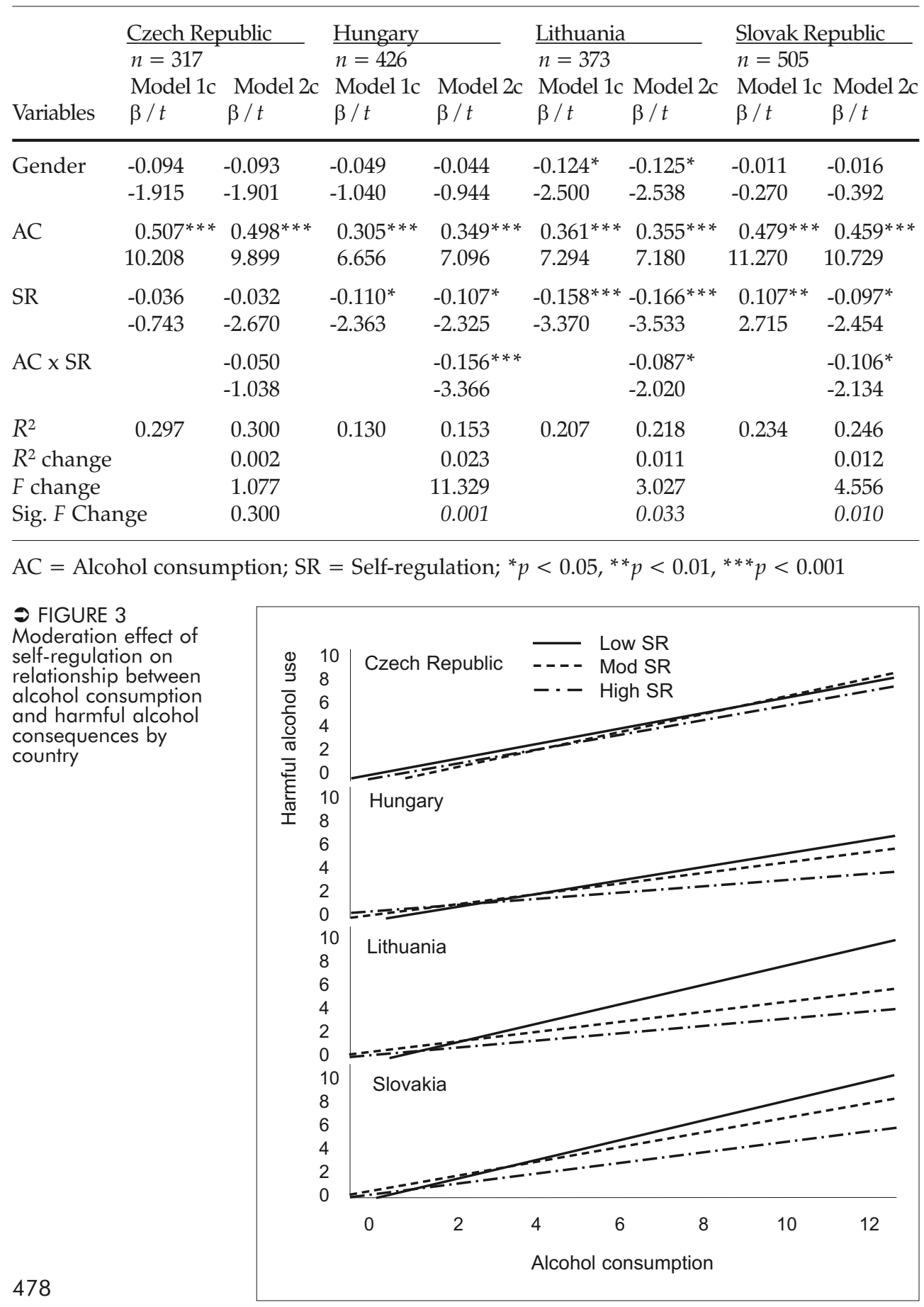


- TABLE 7

Condition effects of normative beliefs on alcohol consumption at $\pm 1 S D$ of self-regulation

() TABLE 8

Condition effects of alcohol consumption on dependence symptoms and harmful alcohol use at $\pm 1 S D$ of self-regulation
Alcohol use

Czech Republic

Estimate $t$

\begin{tabular}{rrrrrrr}
\hline-1 SD SR & 0.191 & 2.006 & 0.046 & 0.545 & 6.825 & 0.000 \\
0 SD SR & 0.045 & 0.653 & 0.515 & 0.437 & 7.786 & 0.000 \\
+1 SD SR & -0.101 & -1.117 & 0.265 & 0.329 & 4.385 & 0.000 \\
\hline
\end{tabular}

$\mathrm{SR}=$ Self-regulation

\begin{tabular}{|c|c|c|c|c|c|}
\hline it-regulatıon & & & Estimate & $t$ & $p$ \\
\hline Czech Republic & Dependence symptoms & $-1 S D$ SR & 0.446 & 10.606 & 0.000 \\
\hline & & 0 SD SR & 0.329 & 10.133 & 0.000 \\
\hline & & $+1 S D$ SR & 0.211 & 4.529 & 0.000 \\
\hline Hungary & Dependence symptoms & $-1 S D$ SR & 0.245 & 8.290 & 0.000 \\
\hline & & 0 SD SR & 0.16 & 7.571 & 0.000 \\
\hline & & $+1 S D$ SR & 0.075 & 2.485 & 0.013 \\
\hline & Harmful alcohol use & $-1 S D$ SR & 0.456 & 8.308 & 0.000 \\
\hline & & 0 SD SR & 0.303 & 7.696 & 0.000 \\
\hline & & $+1 S D$ SR & 0.149 & 2.641 & 0.009 \\
\hline Lithuania & Dependence symptoms & $-1 S D$ SR & 0.262 & 8.196 & 0.000 \\
\hline & & 0 SD SR & 0.192 & 8.332 & 0.000 \\
\hline & & $+1 S D$ SR & 0.121 & 3.676 & 0.000 \\
\hline & Harmful alcohol use & $-1 S D$ SR & 0.486 & 7.649 & 0.000 \\
\hline & & 0 SD SR & 0.388 & 8.486 & 0.000 \\
\hline & & $+1 S D$ SR & 0.290 & 4.420 & 0.000 \\
\hline Slovakia & Harmful alcohol use & $-1 S D$ SR & 0.718 & 9.803 & 0.000 \\
\hline & & 0 SD SR & 0.588 & 12.057 & 0.000 \\
\hline & & $+1 S D$ SR & 0.458 & 6.933 & 0.000 \\
\hline
\end{tabular}

$\mathrm{SR}=$ Self-regulation

\section{DISCUSSION AND CONCLUSION}

In line with previous studies (Brutovská et al., 2015; Helmer et al., 2016), the students in each country reported higher average scores of descriptive normative beliefs than actual alcohol consumption. The regression model predicting alcohol consumption shows that students (except for those in the Czech sample) with higher descriptive normative beliefs towards alcohol use were more likely to consume alcohol than those with lower descriptive normative beliefs. This finding strongly confirms previous findings (Meisel et al., 2015; McAlaney et al., 2015) and supports the theory of social influence in the context of normative beliefs and risky behaviour.

The results also indicate that the relationship between normative beliefs and alcohol use may differ according to the 
DRUŠ. ISTRAŽ. ZAGREB GOD. 30 (2021), BR. 3, STR. $467-485$

KALINA, O. ET AL.: SELF-REGULATION.. individual capacity of self-regulation. In other words, students (Model 2a) with high descriptive normative beliefs towards alcohol use were more likely to drink although this association was stronger among students with low self-regulation and much weaker among students with high self-regulation. This also implies that even if students are exposed to the "alcohol use group culture", those with higher self-regulation seem to be able to stick to their aims and delay gratification in terms of alcohol use. However, the buffering effect of self-regulation varies across countries and the moderation effect of self-regulation was only significant among the Czech and Slovak students.

Similarly, self-regulation moderates the effect of alcohol consumption on negative alcohol consequences - dependence symptoms and harmful consequences. In particular, students from the Czech Republic, Hungary and Lithuania reported weaker associations between alcohol consumption and dependence symptoms when their self-regulation was higher. Similarly, self-regulation moderates the effect of alcohol consumption on harmful alcohol consequences among students from all countries (except those in the Czech sample).

The results of this study are in line with the self-regulation theory in addition to other studies (Hustad et al., 2009; Mullan, 2013; Mann et al., 2013) which have proposed that self-regulation may function as a protective factor against risk behaviour regardless of the risk factors. Alternatively, self-regulation may function as a buffer in the interaction between risk factors and risky behaviour (Quinn \& Fromme, 2010). Moreover, the results emphasise that the buffering effect of self-regulation is stronger in the relationship between the risk factors (alcohol consumption) and negative consequences than in the relationship between normative beliefs and alcohol consumption. This might indicate the presence of other factors which can determine a different moderation effect of self-regulation. A study by Quinn \& Fromme (2010) found that sensation seeking might disrupt the moderation effect of self-regulation between heavy episodic drinking and unprotected sex. A further explanation could be that the relationship between self-regulation and alcohol consumption is likely to be bi-directional (Mullan, 2013). This assumption can be specifically applied when self-regulation is treated as the executive function and that alcohol or substance use can significantly deplete the executive functioning of self-regulation. On the other hand, a recent review of self-control and health behaviour has concluded that self-regulatory capacity seems to be a key factor in predicting intentional models of health behaviour (Hagger et al., 2013). 
DRUŠ. ISTRAŽ. ZAGREB GOD. 30 (2021), BR. 3, STR. 467-485

KALINA, O. ET AL.: SELF-REGULATION..
It is also important to recognise the limitations of this study. The reported rates of alcohol use and the consequences might not have been fully representative for all countries or for the university population for two reasons. Firstly, the initial study sample dropped by $40 \%$ (the results of the attrition analyses were discussed in the methods section) due to missing responses in the explored variables. Secondly, it was not possible to report whether the study had reached all first-year university students in each faculty. This was due to the self-selection nature of participation. The fact that students filled in a multi-topic questionnaire could have reduced the possible selection bias. However, this study primarily looked at the associations at the individual level rather than describing the prevalence of alcohol use and consequences, normative beliefs and self-regulation. Therefore, representativeness might not be the greatest threat. Another limitation of this study is its cross-sectional design which limits the potential for inferences about causality. It can only be assumed that normative beliefs increase alcohol consumption or that self-regulation may reduce this effect despite the fact that some longitudinal studies support this assumption (Quinn \& Fromme, 2010; Mullan, 2013). Moreover, the external validity of the results may be restricted by the nature of the study sample. It is possible that the levels of the explored variables in this study are likely to be different from those who do not attend university.

In conclusion, the study has highlighted the importance of researching alcohol use among first year university students and the patterns in which descriptive normative beliefs and self-regulation are linked to alcohol use in different countries. The findings suggest that the role of descriptive normative beliefs on alcohol use may differ according to country, as alcohol use among the Czech students did not differ despite students overestimating their peers' alcohol use as being twice as high compared to their actual behaviour. However, the previous non-significant associations between descriptive normative beliefs and alcohol consumption have changed as self-regulation plays a role. The Czech students with low levels of self-regulation were found to drink significantly more than students with high levels of self-regulation. This may indicate crucial information regarding the implementation of intervention or prevention programmes based on normative influences among young students in the Czech Republic. In the other countries, descriptive normative beliefs towards peer alcohol use were strongly associated with higher alcohol consumption. This relationship was significantly moderated by self-regulation (Slovak students), as the students with low 
DRUŠ. ISTRAŽ. ZAGREB GOD. 30 (2021), BR. 3, STR. 467-485

KALINA, O. ET AL.: SELF-REGULATION.. self-regulation were more likely to drink compared to those with high self-regulation. In contrast to the Czech students, a positive relationship between descriptive normative beliefs and alcohol consumption among Slovak students remained significant for students with low or with high self-regulation, although the strength of the effect dropped. Similarly, higher alcohol consumption was strongly related to dependence symptoms and harmful alcohol consequences. Both of these relationships were moderated by self-regulation. According to the results, self-regulation may be considered as a protective factor in at least two ways. Firstly, self-regulation significantly buffers against the high alcohol consumption associated with high normative beliefs as well as buffering against the alcohol consequences (dependence symptoms and harmful alcohol use) associated with alcohol consumption. Secondly, self-regulation was found to be protective in the overall effect on alcohol use and alcohol consequences. The results pertaining to self-regulation as a moderator show slightly more consistent and significant results across the countries regarding negative alcohol consequences. This indicates that from the individual perspective self-regulation functions against alcohol use in situations where one overestimates peers' behaviour, although it functions even more consistently against harmful alcohol use and dependence symptoms.

\section{REFERENCES}

Babor, T., Eiddle, J. H., Saunders, J., \& Monteiro, M. (2001). The alcohol use disorders identification test - Guidelines for use in primary care Second Edition. World Health Organization: Department of Mental Health and Substance Dependence.

Baer, J. S., Kivlahan, D. R., \& Marlatt, G. A. (1995). High-risk drinking across the transition from high school to college. Alcoholism: Clinical and Experimental Research, 19(1), 54-61. https://doi.org/10.1111/j.1530-0277. 1995.tb01472.x

Baumeister, R. F., \& Vohs, K. D. (2007). Self-regulation, ego depletion, and motivation. Social and Personality Psychology Compass, 1(1), 115-128. https://doi.org/10.1111/j.1751-9004.2007.00001.x

Boot, C., Dahlin, M., Lintonen, T., Stock, C., Van Hal, G., Rasmussen, S., \& McAlaney, J. (2012). A survey study on the associations between misperceptions on substance use by peers and health and academic outcomes in university students in North-West Europe. International Journal on Disability and Human Development, 11(3), 273-279. https://doi. org/10.1515/ijdhd-2012-0027

Borsari, B., \& Carey, K. B. (2003). Descriptive and injunctive norms in college drinking: A meta-analytic integration. Journal of Studies on Alcohol, 64(3), 331-41. https://doi.org/10.15288/jsa.2003.64.331 
DRUŠ. ISTRAŽ. ZAGREB GOD. 30 (2021), BR. 3, STR. 467-485

KALINA, O. ET AL.: SELF-REGULATION..
Brutovská, M., Orosová, O., Kalina, O., \& Šebeňa, R. (2015). Descriptive normative beliefs and self-regulation in alcohol use among Slovak university students. Journal of Public Health, 37(4), 618-624. https://doi. org/10.1093/pubmed/fdu099

Carey, K. B., Neal, D. J., \& Collins, S. E. (2004). A psychometric analysis of the self-regulation questionnaire. Addictive Behaviors, 29(2), 253-260. https://doi.org/10.1016/j.addbeh.2003.08.001

Cialdini, R. B. (2009). Influence: Science and practice. Allyn and Bacon.

Cohen, J., \& Cohen, P. (1983). Applied multiple regression/correlation analysis for the behavioral sciences (2nd Ed.). Erlbaum

Corbin, W., Iwamoto, D., \& Fromme, K. (2011). A comprehensive longitudinal test of the acquired preparedness model for alcohol use and related problems. Journal of Studies on Alcohol and Drugs, 72(4), 602-610. https://doi.org/10.15288/jsad.2011.72.602

Dempsey, R. C., McAlaney, J., \& Bewick, B. M. (2018). A critical appraisal of the social norms approach as an interventional strategy for health-related behavior and attitude change. Frontiers in Psychology, 9, 2180. https://doi.org/10.3389/fpsyg.2018.02180

European Monitoring Centre for Drugs and Drug Addiction (2019), European Drug Report 2019: Trends and Developments. Publications Office of the European Union, Luxembourg. http://www.emcdda.europa. eu/system/files/publications/11364/20191724_TDAT19001ENN_PDF. pdf (accessed 17 May 2019).

Griskevicius, V., Goldstein, N. J., Mortensen, C. R., Cialdini, R. B., \& Kenrick, D. T. (2006). Going along versus going alone: When fundamental motives facilitate strategic (non)conformity. Journal of Personality and Social Psychology, 91(2), 281-294. https://doi.org/10.1037/ 0022-3514.91.2.281

Hagger, M. S., Wood, C., Stiff, C., \& Chatzisarantiset, N. (2009). The strength model of self-regulation failure and health-related behavior. Health Psychology Review, 3(2), 208-238. https://doi.org/10.1080/ 17437190903414387

Hall, P. A. (2013). Social neuroscience and public health. Springer. https://doi. org/10.1007/978-1-4614-6852-3

Helmer, S. M., Sebena, R., McAlaney, J., Petkeviciene, J., Salonna, F., Lukács, A., \& Mikolajczyk, R. T. (2016). Perception of high alcohol use of peers is associated with high personal alcohol use in first-year university students in three Central and Eastern European countries. Substance Use \& Misuse, 51(9), 1224-1231. https://doi.org/10.3109/1082 6084.2016.1162810

Hofmann, W., Friese, M., \& Strack, F. (2009). Impulse and self-control from a dual-systems perspective. Perspectives on Psychological Science, 4(2), 162-176. https://doi.org/10.1111/j.1745-6924.2009.01116.x

Hustad, J. T. P., Carey, K. B., Carey, M. P., \& Maisto, S. A. (2009). Self-regulation, alcohol use, and consequences in college student heavy drinkers: A simultaneous latent growth analysis. Journal of Studies on Alcohol and Drugs, 70(3) 373-382. https://doi.org/10.15288/jsad.2009. 70.373 
DRUŠ. ISTRAŽ. ZAGREB GOD. 30 (2021), BR. 3, STR. 467-485

KALINA, O. ET AL.: SELF-REGULATION..
Jacobson, R. P., Mortensen, C. H. R., \& Cialdini, R. B. (2011). Bodies obliged and unbound: Differentiated response tendencies for injunctive and descriptive social norms. Journal of Personality and Social Psychology, 100(3), 433-448. https://doi.org/10.1037/a0021470

Lindgren, K. P., Neighbors, C., Westgate, E., \& Salemink, E. (2014). Self-control and implicit drinking identity as predictors of alcohol use, problems, and cravings. Journal of Studies on Alcohol and Drugs, 75(2), 290-298. https://doi.org/10.15288/jsad.2014.75.290

Lorant, V., \& Nicaise, P. (2015). Binge drinking at university: A social network study in Belgium. Health Promotion International, 30(3), 675-683. https://doi.org/10.1093/heapro/dau007

Mann, T., de Ridder, D., \& Fujita, K. (2013). Self-regulation of health behavior: Social psychological approaches to goal setting and goal striving. Health Psychology, 32(5), 487-498. https://doi.org/10.1037/a0028533

McAlaney, J., Helmer, S. M., Stock, C., Vriesacker, B., Van Hal, G., Dempsey, R. C., Akvardar, Y., Salonna, F., Kalina, O., Guillen-Grima, F., Bewick, B. M., \& Mikolajczyk, R. (2015). Personal and perceived peer use of and attitudes toward alcohol among university and college students in seven EU countries: Project SNIPE. Journal of Studies on Alcohol and Drugs, 76(3) 430-438. https://doi.org/10.15288/jsad2015.76.430

Meisel, S. N., Colder, C. R., \& Hawk, L. W. (2015). The moderating role of cognitive capacities in the association between social norms and drinking behaviors. Alcoholism: Clinical and Experimental Research, 39(6), 1049-1056. https://doi.org/10.1111/acer.12710

Meisel, M. K., \& Barnett, N. P. (2017). Protective and risky social network factors for drinking during the transition from high school to college. Journal of Studies on Alcohol and Drugs, 78(6), 922-929. https://doi. org/10.15288/jsad.2017.78.922

Mullan, B. (2013). Alcohol use and self-regulation. In P. A. Hall (Ed.), Social Neuroscience and Public Health (pp. 109-122). Springer. https://doi.org/ 10.1007/978-1-4614-6852-3_7

Neal, D. J., \& Carey, K. B. (2005). A follow-up psychometric analysis of the self-regulation questionnaire. Psychology of Addictive Behaviors, 19(4), 414-422. https://doi.org/10.1037/0893-164X.19.4.414

Quinn, P. D., \& Fromme, K. (2010). Self-regulation as a protective factor against risky drinking and sexual behavior. Psychology of Addictive Behaviors, 24(3), 376-385. https://doi.org/10.1037/a0018547

Reynolds, B., Penfold, R. B., \& Patak, M. (2008). Dimensions of impulsive behavior in adolescents: Laboratory behavioral assessments. Experimental and Clinical Psychopharmacology, 16(2), 124-131. https://doi. org/10.1037/1064-1297.16.2.124

Vallentin-Holbech, L., Rasmussen, B. M., \& Stock, C. (2017). Are perceptions of social norms regarding peer alcohol and other drug use associated with personal use in Danish adolescents? Scandinavian Journal of Public Health, 45(8), 757-764. https://doi.org/10.1177/1403494817724313

Vohs, K. D., \& Baumeister, R. F. (Eds.) (2011). Handbook of self-regulation: Research, theory, and applications (2nd Ed.). Guilford Press. 
DRUŠ. ISTRAŽ. ZAGREB GOD. 30 (2021), BR. 3, STR. 467-485

KALINA, O. ET AL.: SELF-REGULATION...
Samoregulacija, normativna uvjerenja, posljedice upotrebe alkohola među studentima istočne Europe

Ondrej KALINA, Olga OROSOVA

Fakultet umjetnosti, Sveučilište Pavol Jozef Šafárik u Košicama, Košice, Slovačka

Vilma KRIAUCIONIENE

Fakultet za javno zdravstvo, Litvansko sveučilište zdravstvenih znanosti, Kaunas, Litva

Andrea LUKÁCS

Fakultet medicinske skrbi, Sveučilište u Miskolcu, Miskolc, Mađarska

Michal MIOVSKY

Prvi medicinski fakultet, Karlovo sveučilište, Prag, Češka Republika

Cili je ove studije istražiti povezanost opisnih normativnih uvjerenja (descriptive normative beliefs, DNB), uživanja alkohola i njegovih štetnih posljedica te provjeriti umanjuje li samoregulacija ovaj odnos. Podaci su prikuplieni na internetu od 1621 studenta prve godine sveučilišta u Češkoj, Mađarskoj, Litvi i Slovačkoj. Korišteni su upitnici AUDIT, upitnik za samoregulaciju i pitanja o DNB-u. U svim je uzorcima DNB pozitivno povezan s konzumacijom alkohola. Povezanost između DNB-a i uživanja alkohola, kao i između uživanja alkohola i njegovih štetnih posljedica bila je jača kod studenata s nižom samoregulacijom. Zaštitni učinak samoregulacije na konzumaciju alkohola i njegove posljedice, u kombinaciji s teorijom društvenog utjecaja, mogu poboljšati točnost intervencije i učiniti je obećavajućom mjerom djelovanja među mladim odraslim osobama.

Ključne riječi: samoregulacija, opisna normativna uvjerenja, posljedice uživanja alkohola, studenti prve godine fakulteta

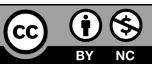

Međunarodna licenca / International License:

Imenovanje-Nekomercijalno / Attribution-NonCommercial 